\title{
Tumors: Benign and Malignant
}

\author{
Tarini Sinha* \\ Jayoti Vidyapeeth Women's University, Jaipur
}

Submission: April 27, 2018; Published: May 01, 2018

"Correspondence Address: Tarini Sinha, Radiation student, Jayoti Vidyapeeth Women's University, Jaipur, Rajasthan

\section{Introduction}

A tumor is a pathologic disturbance of cell growth, characterized by excessive and abnormal proliferation of cells. Tumors are abnormal mass of tissue which may be solid or fluid filled. When the growth of tumor cells confined to the site of origin and are of normal physicality they are concluded as benign tumors. When the cells are abnormal and can grow uncontrollably, they are concluded as cancerous cells i.e. malignant tumor. Tumors are also called as 'NEOPLASM'. To determine whether a tumor is benign or cancerous, a doctor can take a sample of the cells with a biopsy procedure. Then the biopsy is analyzed under a microscope by a pathologist (a doctor specializing in laboratory science).

\section{Benign Tumors: Noncancerous}

If the cells are non-cancerous, the tumor is concluded as benign. It won't invade nearby tissues or spread to other areas of the body (metastasize). A benign tumor is less harmful unless it is present nearby any important organs, tissues, nerves, or blood vessels and causing damage. Fibroids in the uterus and breast, polyps of colon and moles are some examples of benign tumors. Benign tumors can be removed by surgery. They can grow very large, sometimes weighing pounds. They can be dangerous, such as when they occur in the brain and crowd the normal structures in the enclosed space of the skull. They can press on vital organs or block channels. Also, some types of benign tumors such as intestinal polyps are considered as precancerous and are removed immediately to prevent them becoming malignant. Benign tumors usually don't reoccur once removed, but if they do it is usually in the same place.

Examples: Moles, Fibroid cyst in breast or uterus, polyps of colon.

\section{Malignant Tumors: Cancerous}

Malignant means that the tumor is made of cancer cells and it can invade nearby tissues. Some cancer cells can move into the bloodstream or lymph nodes, where they can spread to other tissues within the body-this is called metastasis. Cancer can occur anywhere in the body including the breast, lungs, intestines, reproductive organs, blood, or skin. For example, breast cancer begins in the breast tissue and may spread to lymph nodes in the armpit if it's not caught early enough and treated. Once breast cancer has spread to the lymph nodes, the cancer cells can travel to other areas of the body, like the bones or liver. The breast cancer cells can then form tumors in those locations referred as secondary tumor. A biopsy of these tumors might show characteristics of the original breast cancer tumor.

Examples: Breast cancer, skin cancer.

\section{Differences Between Benign and Malignant Tumors}

There are many important differences between benign and malignant tumors which are as follows:

i. On the Basis of Growth rate: Generally malignant tumors grow more rapidly than benign tumors, although there are slow-growing and fast-growing tumors in either category.

ii. On the basis of Ability to invade locally: Malignant tumors use to invade the tissues around them. One of the most prominent hallmarks of cancer is penetration of the basal membrane that surrounds normal tissues.

iii. On the Basis of Ability to spread at distance: Malignant tumors may spread to other parts of the body using the bloodstream or the lymphatic system. Malignant tumors may also invade nearby tissues and send out fingers into them, while benign tumors don't. Benign tumors only grow in size at the place of their origin.

iv. On the Basis of Recurrence: Benign tumors can be removed completely by surgery as they have clearer boundaries, and as a result, they are less likely to reoccur. If they do reoccur, it is only at the original site. Malignant tumors may spread to other parts of body. They are more likely to reoccur such as breast cancer recurring in the lungs or bones.

v. On the Basis of Cellular Appearance: When a pathologist looks at tumor cells under a microscope, it is very easy to determine whether they are normal, benign cells or cancerous cells as Cancer cells often have abnormal 
chromosomes and DNA, making their nuclei larger and darker. They also often have different shapes than normal cells. However, sometimes the difference is subtle.

vi. On the Basis of Systemic effects: There are some benign tumors that secrete hormones, such as benign pheochromocytomas, malignant tumors are more likely to do so. Malignant tumors can secrete substances that cause effects throughout the body, such as fatigue and weight loss. This is known as paraneoplastic syndrome. vii. On the Basis of Treatments: A benign tumor can usually be completely treated with surgery, although some may be treated with radiation therapy or chemotherapy. Some benign tumors are not treated as they are not posing any health risk. Malignant tumors may require chemotherapy, radiation therapy, or immunotherapy medications to eliminate a tumor cell that still remains after treatment or to treat secondary tumors present at other parts of the body (Figure 1).

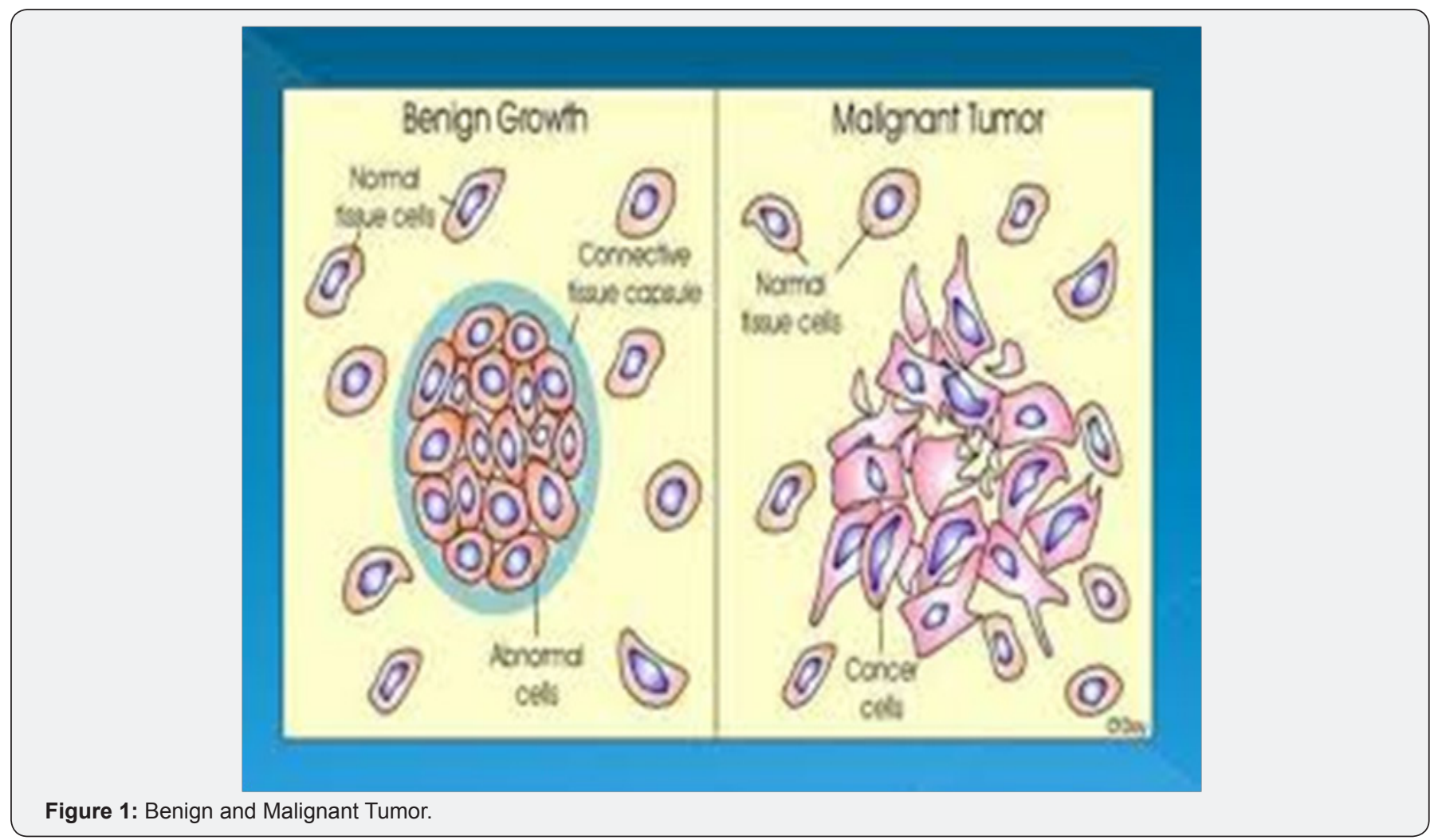

\section{Can a Benign Tumor Turn into Malignant?}

Rarely some types of benign tumors transform into malignant tumors. But tumors like adenomatous polyps (adenomas) in the colon have a greater risk of transforming into malignant tumor. That is why polyps, which are benign, are removed during colonoscopy to avoid further complications. Removing them is one way of preventing colon cancer. It's not always clear-cut whether a tumor is benign or malignant that's why doctors use several different factors to diagnose it as one or the other. Sometimes it may end up with an uncertain diagnosis. Also, it is possible that a biopsy finds precancerous cells or misses the area where the cancerous cells are more prevalent. In these cases, what was thought to be benign might turn out to be malignant as it further grows and develops. 
This work is licensed under Creative Commons Attribution 4.0 License

DOI: $10.19080 /$ CTOIJ.2018.10.555790

\section{Your next submission with Juniper Publishers} will reach you the below assets

- Quality Editorial service

- Swift Peer Review

- Reprints availability

- E-prints Service

- Manuscript Podcast for convenient understanding

- Global attainment for your research

- Manuscript accessibility in different formats

( Pdf, E-pub, Full Text, Audio)

- Unceasing customer service

Track the below URL for one-step submission https://juniperpublishers.com/online-submission.php 